\section{Ethical Lingua}

Journal of Language Teaching and Literature

ISSN 2355-3448 (Print)

ISSN 2540-9190 (Online)

Volume 6, Number 2, August 2019

pp. $164-172$

\title{
Contextual Meanings of the English Terms Used in Hotel
}

\author{
Arny Irhani Asmin \\ arnyirhani@uncp.ac.id \\ Universitas Cokroaminoto Palopo, Indonesia \\ Received : 2 August 2019; Accepted: 22 September 2019 \\ DOI : : https://doi.org/10.30605/25409190.v6.164-172
}

\begin{abstract}
This paper presents the contextual meanings of the English terms used by the staff in Claro Hotel Makassar. The researcher observed three departments in a hotel; they are Housekeeping, Front Office and Food \& Beverage department. The result of the research shows that there are many types of the English terms used in hospitality; some of the terms are categorized as the English special terms due to its contextual meaning. Furthermore, the researcher found that almost all staffs understand the terms even though they do not speak English fluently. However, for the new employer and trainee, most of them are somewhat distressed and said they did not know the terms because their educational background is not hospitality and the trainee said that some of the terms are not in their school textbook. Thus, it is essential for the English for Specific Purposes practitioners and particularly for the teachers of English for Hotel to understand and teach the contextual meanings of the English terms used in the hotel industry.
\end{abstract}

Keywords: contextual meaning, hotel terms, English for Hotel 


\section{Introduction}

Language cannot be separated from the existence of human life. It is a medium to transmit ideas of inter-human relationship, religion, business, education, mass communication, law, medicine, hotel, and tourism. Language can eliminate misunderstanding by using it as an instrument to transfer communication among people. One of the requirements to communicate in society or a particular environment is the common understanding and meaning. The information presented should be equal to be understood, both by speakers and listeners. A communication will run smoothly if the language used can be understood so that the message can be received by the speakers' listeners well. The fact related to the relationships between language and society has long intrigued linguistic. People influence language and language use, and language plays a fundamental role in emotion and intercultural communication (Lindquist, MacCormack, \& Shablack, 2015).

Therefore, language can be varied depending on the situation where the language is used (Blue \& Harun, 2003). For example, the English word used in the hospitality industry may have a different meaning with the general English words. Luo (2011) writes that word meanings may change from context to context; some uses are only meaningful in specific contexts, not in others. In line with Mahdad (2012) writes that language may vary between speakers of different regions or socio-economic background, and it can also vary within the same speaker when she/he moves from formal to an informal situation. The use of words in specific circumstances then called specialized terminology; these words can have different meanings depending upon what words are around it. In Cambridge dictionary, "terms" mean the special words or expressions used in relation to a particular subject or activity, it is a system of words used to name things in a particular discipline. For instance, in education, we know some terminologies like "lesson plan," "rubric," and "term paper," while in Medical, there are special terminologies such as "blood work," "scalpel" and "set." In different situations, people will shift into different terminology. Thus, knowing the terms is an essential part of being able to work in a given profession.

Therefore, to understand the meanings of this kind of terminology, people need to comprehend the context where the words are used or what we called contextual meanings. Meanings are in people not in words (Adler, Rodman, \& du Pre, 2013; Ruhly, 1982), while Klopf (1998) classified meanings as denotative, connotative, contextual, and figurative. Words have set meanings, and these meanings tend to stand independent of the context in which they are used (Adler et al. 2013; Klopf 1998). Other than that, language and attitude also have a complicated relationship be, and it is likely to vary according to the social context (McKenzie, R. M., 2008). In the hotel industry, employees tend to use a formal 
Asmin:

and friendly expression in communicating; it is called hospitality language. Longman (1992: 275) says that context means the part of speech of words and the things denoted. While Simon \& Schuster (1982:10) say that context is the interrelated condition in which something exists or occurs. According to Attardo (2016), context is bounded by the simple requirement that speakers do not try to optimize their interpretation or calculation, but somewhat satisfied. Contextual meaning involves the function of a word in sentence formation since different arrangement of the same word can convey different context, or different situation may give different meaning in a sentence. According to Crystal (2003), contextual meaning defined as the information signaled about the kind of use a linguistic unit has in its social context. Thus, it can be said that contextual meaning is the meaning of the words according to the situation in which they are used.

Therefore, in this paper, the researcher discussed the contextual meanings of the special terms used by the staff to communicate with guests and co-workers in Claro Hotel Makassar. As we currently know, the number of hotel chains in Indonesia was increasing significantly. The International Hotel Association's report on the challenges facing hotels recommends that employers in the industry ensure adequate training at all levels including improving language tuition Cooper, Fletcher, Gilbert \& Wanhill in Hobson (1998:9). People travel for many reasons, whether abroad or domestically and hotel staff cannot avoid direct or indirect interaction with the foreign guest. The staffs are expected to be effective communicators and offer outstanding service to the guests. In the hospitality industry, communication skills and competence in using English sufficiently to communicate with foreign guests is an essential factor in facilitating the financial success of the tourism and hospitality sectors (Hsu, 2014; Shieh, 2012).

Moreover, the function of English as an international language played a significant role in the hotel business. In the hospitality industry, English language commonly used as a second language not only to communicate with the foreign guests, but it is also used in hotel brochures, room names, hotel facilities, and other services. The officers of the hotel needed to prepare for English skill usage during working. For them who work at the back office, they are not actively involved in oral communication with foreign guests but still need to understand the terms of hospitality that can be found in almost texts such as hotel brochures and correspondence. On the other hand, for those who work on the front line, active English is essential because they often communicate directly with foreign guests. The need for communication, both passive and active in the world of hospitality, must begin with an understanding of the vocabulary that they use in hospitality. Based on the experience of researcher when working at the hotel, many of the new employees of the hotel especially for them who have an educational background, not from a hospitality school felt confused about the English terms used in the hotel, this is because they are always translated the words according to general dictionary or the lexical meaning. 
Research field on the English terms in a hotel is essential to conduct. Thus, the research is intended to contribute to the linguistics discipline and as a guideline that could be used as reference and information for the improvement material of the English for Hotel subject and the English for Specific Purposes $(E S P)$ in general.

\section{Method}

In order to understand the contextual meanings of the hotel vocabulary, the researcher applied qualitative method. Therefore, in addition to participant observation, interview to the hotel staffs and review documents were used to gather data for the study. The observation was done for three months in three departments; they are Housekeeping, Front Office and Food \& Beverage Departments. For the interview, the researcher applied a semi-structured interview. Fifteen staffs who were working as the permanent staff at the Claro Hotel Makassar both office staff and operational staff were selected as the participants in this session. As the supporting data, the researcher also gathered information through document review. The documents review were all kinds of forms, report or other documents which are used in the hotel such as; lost and found form, laundry list, reprimand form, equipment checklist, daily hotel event, and brochures.

\section{Results}

The researcher presented at, involved in, and recorded the daily routine activities of the staff at the research site in order to gain an in-depth overview of the context in which the English terms were used. Here, the researcher used field notes; observation checklist and audio recorder to record what occurred and happened in the field. In order to support the data obtained during the observation the researcher conducted a semi-structured interview with the staff and review the documents.

In Housekeeping department, commonly the staff used Bahasa Indonesia in communicating with co-workers and local guests. Some of the staff, such as the Room Attendant staff and Room Supervisor who oversee the floors, and contact the guests directly, used English to communicate with foreign guests. Therefore, most of the terms used in the Housekeeping department were in English, such as for equipment name or various types of services and positions. Majority of the staff used the English terms to mention the name of the services or types of equipment used in their section only, while Bahasa Indonesia still becomes the common language at the Claro Hotel. However, for the staff who in charge as the front liner whose job is to meet the guests, the English language skills must be possessed. 
Asmin:

In observation, the researcher observed the administration staff first called Order Taker as the center of all activities in Housekeeping. Order taker is the staff on duty as operator, administration and received orders and phoned in the Housekeeping department. Here, the researcher heard and noted same of the English terms used by Order Taker staff, such as: vacant ready, vacant clean, vacant dirty, make up room, morning call, high season, low season, check out, check-in, room supervisor, extension, delivery, amenities, Lost and Found form, storeroom request, room attendant control sheet and a list of amenities.

\section{"Vacant Dirty," "Vacant Ready," \& "Vacant Clean"}

Vacant Dirty room (VD) generally means an empty and dirty room. In the hotel, the contextual meaning of 'Vacant Dirty' refers to an empty room but cannot be sold to the guest because the room is not cleaned yet and the amenities for the room have not been prepared. In the hotel, after the guest checked out the room status in the computer system of the Housekeeping and Front Office department automatically VD (Vacant Dirty), when the receptionists want to sell the room to the guest, they have to check the room in the computer system and make sure that the room status was VR (Vacant Ready). Before the status of the room become VR, the room attendant usually changes the status from VD to VC (Vacant Clean). Vacant Clean means that the room has been cleaned, just lacking bit completeness. When the receptionist wants to sell the room, they will ask the room supervisor of Housekeeping to complete the room, after that room status on Computer System will be VR or Vacant Ready. Thus, the contextual meaning of 'Vacant Ready' in the hotel context means the room that was ready for sale.

\section{"Make Up Room"}

Another term that is frequently used by the staff of Housekeeping is 'Make up Room.' From the observation, the researcher interpreted that the use of this term in a contextual situation is crucial because when the guest wants their room to be cleaned, the room attendant must prioritize the room. The supervisor also instructed to put full amenities when the staff was making up a room. It can be said that the room will be back neatly, as usual. Usually, make-up room requested by telephone or by hanging sign "Please Makeup" on the door. Thus, the contextual meaning of 'Make-up room' refers to a term used by the guest when asking for the room to be cleaned by the Housekeeping staff.

'Making Bed' in a contextual situation in the hotel means an activity to tidy up the bed according to the initial standard of the hotel. Making bed is one of the duties of the Room Attendant (Room Maid) when makeup the room. The contextual meaning of 'Sleep Out' in hospitality is when the guest decides to sleep outside the hotel or sometimes in another room. Moreover, the term 'Occupied No Luggage' (ONL) used by the Housekeeping and the Front Office staff to explain the real situation in the occupied room. In this case, the room 
status is occupied, but the guests were not in the room, the staff only found the guest's stuff in the room. The term 'Jumping' in contextual meaning is when the staff should be further work on early shift after she/he finished at the end shift.

\section{The Food \& Beverage Department}

Food \& Beverage Department is a department in the hotel which is tasked to preparing food and drink for hotel guests. There are different skills of chefs in the hotel who cook and prepare meals for guests. This department has several outlets, namely Restaurants, Bars \& Lounge, Room Service, Kitchen, Banquet and, Product. The following data were obtained through observation, interview and review of documents from several sections that exist in the Food \& Beverage (F\&B) department, such as; F \& B secretary, Order Taker, Room Service Attendant, Cashier of Café and Restaurant, Banquet staff, and Pastry and Kitchen staff.

The researcher found some of the English terminologies used by the staff in Food \& Beverage department which derived from the French language, such as menu names like Salamander, A'la carte, A'la Minutes, or A'la Dente. Here, the researcher highlighted that English terms that were taken in this research were the original English terms which were not derived from other languages. In other words, the special terms taken were the English special terms for $F$ \& B in the hotel which used in daily work activity of the hotel staff.

From the observation in the $F$ \& B department, the researcher found several English terminologies such as follow up, banquet, order taker, clear up, floor man, captain, and additional items. Some English terms found here also similar to the terms used by the staff of the Housekeeping and Front Office department, such as check out, check-in, arrival, departure, cash basis, deposit, and cash.

In the Food \& Beverage Department, the staff commonly uttered this verb 'Follow up' to take on the guest's request immediately. Besides, the term 'clear up' has the contextual meaning as to remove all foods, plates, and cutlery from a table at the end of a meal, clear the table quietly when dessert is finished and take all items borrowed by guest from room service in the guest room. Furthermore, the term 'Order Taker (OT)' in the F \& B department has the same function as the Order Taker in the Housekeeping department. This term refers to the staff that has the responsibility to receive orders via telephone by the guests or the operator of Room Service. This staff also handles the administration of the Room Service section.

Another term is 'Captain,' in the hospitality industry this term has a different meaning to the general English. In the hotel, the term 'Captain' refers to a staff that is in charge as a supervisor in F \& B department, he/she supervised the performance of the room service attendants, handled orders given by the Order Taker and sometimes also delivers the meals to the guest. The 'Floor Man' is the 
Asmin:

staffs of $F$ \& B department who stands by on the floor and wait for the Captain give task direction, in other words, this staff is the one which immediately follows up the guest request from the guest room.

From observation in the Food \& Beverage department, the researcher found several documents used by the staff such as Equipment Check List, Guest Satisfactory Survey, VIP Request Form, Room Service Order Form, Banquet Event Order, Arrival list, Departure List, Menu List, Receipt Form and several types of brochures.

\section{Discussion}

From the findings, the researcher found that most terms used by the staff in the Claro Hotel Makassar was in English. There are many variations of English terms used in the research site which have a similar meaning to the general English, while some of them can be categorized as special terms due to its meanings are different to the general English. All hotel around the world have one thing in common; they use English as their lingua franca.

Additionally, most of the English terminologies of the hotel found were in the form of a noun. The terms were used as the name of the rooms, types of equipment, tools, areas, job titles, and services. The verb form was also quite much found because it was undoubtedly related to the provision of the services provided by the hotel as a service industry. Based on the observation, the researcher found that most of the terms used by the staff were brought by the staff that moving from another hotel, which was subsequently accepted and used by other staff, there were no settings what terms to use, almost entirely derived from the terms that brought or spoken by transfer staff from other hotels.

The staffs who have been working for about one year are able to understand the contextual meanings of the terms, because they are used to listening and using the terms. Unfortunately, some of them pronounce the terms differently from standard English pronunciation. Meanwhile, for the new employees who have been working less than six months and the trainees or intern students from tourism and hotel vocational high school, they still confused about the contextual meanings of these terms due to their educational background is not hotel major. The trainees said that majority of the terms are not in their school textbook. Moreover, they are also not confident with their English skills.

According to Chang (2009); Tsao (2011); \& Tse (2010), the learners who are obligated to meet the essential, specific and precise needs to respond to the considerable demands in vocational or academic situations in English are encouraged to learn English for Specific Purposes. However, the current English textbook used at vocational high school is the same as senior high school. Then, it is predicted that the English used in the vocational school textbook is general. 
Therefore, it is essential to prepare students who will work in the hotel industry with excellent English skills. Learning English in vocational high school is classified as English for Specific Purposes (ESP), and the purpose of learning English depends on the department or students' major. As non-native English speakers, the students at least understand words and terms used in the hotel industry. In line with this, Cunningsworth (1995) said that selecting vocabulary is a hard subject and not as simple as could be hoped. He also stated that ESP material should meet learners' needs and that the language taught should match the language that the students will use. Thus, for teachers who teach in tourism and hotel vocational school, the researcher hopes that this paper can help them understand some English terms used in a domestic hotel. Students need to learn sufficient vocabulary that they will need as hotelier. Hotel vocabularies have contextual meanings, therefore understanding the situational relationship and semantic relationship of hotel words is essential to be learned by the students of hotel major. The learners should be able to use what they have learned to perform their job effectively. Therefore, in designing English material for hotel major, the teachers should consider who will be taught in order to give appropriate materials for them because teaching methods and contents used in English for Specific Purposes are not the same as in General English.

\section{Conclusion}

Based on the research results, it can be concluded that the majority English terms used in Claro Hotel Makassar have its contextual meanings. However, some of employees and trainees did not understand the meaning of the terms. Thus, the researcher thinks that it is essential for the English for Specific Purposes practitioners and particularly for the teachers of English for Hotel to understand and teach the contextual meanings of the terms used in the hotel industry. Moreover, the researcher expected that the result of this research could be assistance to the ESP practitioners, especially for those who teaching and designing material related to English for Hotel. Besides, the researcher hopes that the result of this research can contribute to the development of English for Hotel textbook which in turn will contribute to the English Language Teaching (ELT) and Teaching English as a Foreign Language (TEFL).

\section{References}

Adler, R. P., Rodman, G., \& du Pre, A. (2013). Understanding human communication.

New York, NY: Oxford University Press.

Attardo, S. (2016). Context as relevance-driven abduction and charitable satisficing.

Frontiers in Psychology, 7, 305. https://doi.org/10.3389/fpsyg.2016.00305

Blue, G. M., \& Harun, M. (2003). Hospitality language as a professional skill. English for

Specific Purposes, 22(1), 73-91. https://doi.org/10.1016/s0889-4906(01)00031-X

Cunningsworth, A. (1995). Choosing your coursebook. London: Macmillan Heinemann. 
Asmin:

Chang, W. Y. (2009). A need analysis of applying an ESP program for hotel employees. Yu Da Academic Journal, 21, 1-16.

Crystal, D. (2003). English as a global language (2nd ed.). Cambridge: Cambridge University Press.

Hsu, L. (2014). Effectiveness of English for Specific Purposes courses for non-English speaking students of hospitality and tourism: A latent growth curve analysis. Journal of Hospitality, Leisure, Sport \& Tourism Education, 15, 50-57. https://doi.org/10.1016/j.jhlste.2014.05.001

Longman. (2013). Dictionary of contemporary English. Oxford University Press.

Luo, Z. (2011). Contextual analysis of word meanings in type-theoretical semantic. LACL, 159-174.

Lindquist, K. A., MacCormack, J. K., \& Shablack, H. (2015). The role of language in emotion: predictions from psychological constructionism. Frontiers in psychology, 6, 444. https://doi.org/10.3389/fpsyg.2015.00444

McKenzie, R. M. (2008). Social factors and non-native attitudes towards varieties of spoken English: A Japanese case study. International Journal of Applied Linguistics, 18(1), 63-88. https://doi.org/10.1111/j.1473-4192.2008.00179.x

Mahdad, H. (2012). Language change and lexical variation in youth language. Published Thesis. University of Tlemcen.

Shieh, W. (2012). Hotel employees' perception on their workplace English use: An example from Taiwan. US-China Foreign Language, 10(11), 1729-1733.

Tsao, C. H. (2011). English for Specific Purposes in the EFL context: A survey of students and faculty perceptions. Asian ESP Journal, 7 (2), 126-149.

Tse, T. S. M. (2010). What do hospitality students find important about internships? Journal of Teaching in Travel and Tourism, 10(3), 251-264. 